\title{
Methods and Problems of Drilling Implantation in Rural Water Supply in the Fractured Basement Area in Chad: Case of Ouaddaï Geographic
}

\author{
Massing Oursingbé (Corresponding author) \& Zhonghua Tang \\ Department of Hydrogeology and Water Resources, School of Environment Studies \\ China University of Geosciences, 430074-Wuhan, Lumo Road 388, Hubei, China
}

Tel: 86-27-5972-3504 E-mail: massing.2@hotmail.com

\author{
Yonoudjoum M. Médard \\ Ministry of Water, Direction of Water Resources and Meteorology, 429 Ndjamena, Republic of Chad
} Tel: 23-5-6620-7704_E-mail: monodjomi1977@yahoo.fr

\begin{abstract}
This study focuses on the Ouaddaï Geographic Region, located on the eastern edge of the Chad basin, along the Sudanese border of Darfur where fracturing is well developed. It aims to highlight the factors affecting the productivity of hydraulic structures by the characterization of fracture networks in crystalline and metamorphic rocks using stereotype resulting from the interpretation of satellite images Landsat-7 ETM + and exogenous data collected in Directorate of the Hydraulics Field Knowledge of Ministry of Water. All techniques resulted in the enhancement of structural and linear elements content in the raw images, enabling better geological cartography. The lineaments map obtained after treatment is very dense and consists of lineaments (discontinuities images) in various sizes. The analysis of these fracture networks has enabled us to highlight the presence of certain tectonic directions $\mathrm{N} 40$ to $60^{\circ} \mathrm{E}$ and $\mathrm{N} 110$ to $130^{\circ} \mathrm{E}$ potentially more favorable. The appearance tectonics is a fundamental criterion for the establishment of hydraulic work. However, satellite images study in comparison with aerial photography makes it possible to know what scale is imperative to make study for a project of rural water supply. The statistic of the various data shows a high flow rate of dry borehole (approximately $60 \%$ ) and nearly $20 \%$ of works have a flow rate ranging between $0.5-1.5 \mathrm{~m}^{3} / \mathrm{s}$. For this propose, many dry boreholes are mostly localized on anomalies associated with fault zones very wide and very marked and conductive. These zones often correspond to shearing zones. On this kind of anomaly, the drillings should be established on geophysical gradients, but not in the center of anomaly which could be systematically plugged. It may also include the cemented areas which the electrical tomography in pole dipole directs and inverse can refine the establishment. In all this analysis, we have made from some recommendations in order to allow raising some ambiguities relating to borehole establishment in fractured basement: carry out the drilling in the border of the large and conductive geophysical anomalies. Indeed; carry out the borehole just in the inselbergs border to verify certain hydrogeological assumptions which consist in saying that border of these massive outcrops is aquifer; and carry out the drilling in hydraulic border upstream of dyke, acid, basic and quartz vein. All these considerations are essential to increase significantly the success rate of the drillings establishment in the basement areas.
\end{abstract}

Keywords: Fractured basement, Ouaddaï geography, Statistics, Productivity, Rural water supply

\section{Introduction}

Water, essential for life and for any economic development, becomes a major strategic challenge in many parts of the globe. But it can also be the vector of epidemic and contribute to human exposure to toxic substances or undesirable. However, the quality of the resource depends in large part to anthropogenic pressure, planning and activities that support the watershed or environment.

However access to safe drinking water is one of the major objectives of development projects around the world. In Chad, many efforts have been made in recent years by the Government under the assistance of Breton Wood Institutions (World Bank) to improve the supply of drinking water to people in general and particularly to rural communities. Thus, several projects on rural water supply have been initiated in Chad.

The concept of rural water supply is to provide drinking water to population isolated starting from drillings generally equipped with hand pumps. The productivity target is modest and drillings are generally declared positives and equipped from obtaining a flow rate greater than $0.5 \mathrm{~m}^{3} / \mathrm{h}$ at the end of drilling. The term 
"productivity" here indicates the ability of aquifer to provide, through a catchment, a minimum flow rate that can be exploited.

For budgetary reasons, the depths of investigation are contractually limited, usually to $60 \mathrm{~m}$. When borehole does not reach this flow whit that depth, it is declared negative and abandoned, and then the building site moves on another site. Despite of more or less rigorous screening by photo interpretation and geophysical investigation, all the survey sites do not have the same chance of success.

Unfortunately, access to groundwater remains random in some territories parts where the aquifers have a certain complexity. Indeed, the research of groundwater in medium of fractured or fissured bedrock is mainly based on the identification of fractures which are witnesses of the tectonic deformation. Thus, drilling which doesn't cross any fracture can not produce water. Therefore, failures are generally many during the drilling campaigns when the establishment is not conducted under optimal conditions.

The region of geographical Ouaddaï, area of our study registered in this hydrogeological context, and of which it poses the problem of rational choice for the sites establishment of the works of catchment area. Despite the technical of prospecting carried out, the failure of drilling can exceed $50 \%$ in the discontinuous bedrock aquifers, which covers nearly $62 \%$ of Central and East Africa [Gombert P., 1997].

Thus, it is to cope with these difficulties which this study was initiated with a new prospecting approach of groundwater exploration by integrating the maximum information. It is a contribution to a better knowledge of the geometry of fracture networks. It makes it possible to highlight the critical factors that influence the productivity of the hydraulic works (drillings \& wells). These lead to determine, in the term, the probable sites for establishment of drilling in order to improve the drillings success at the time of rural water supply campaigns in the study area. Indeed, if the groundwater is increasingly occupying an important place in daily activities (domestic, industrial and agricultural) of geographical Ouaddaï, the accurate information's are essential on the factors which influence the productivity, accessibility as well as the exploitability of aquifers and water drillings.

\section{Characterization of bedrock aquifers}

The aquifers are composed of crystalline rocks of plutonic origin (granite) and metamorphic (gneiss, schist, mica, etc...). From the hydrogeological point of view, it is hard rock which presents a mechanical behavior and hydraulic properties of all relatively homogeneous and which is characterized mainly by a permeability of fissure and fractures. These aquifers are considered as "discontinuous" because of the large spatial variability of their hydrodynamic properties [L. Patrick, Robert W., 2005]. These basement rocks (plutonic and metamorphic rocks) are aquifers only within their superficial fringe on the first 100 meters approximately under the ground surface[R. Taylor, K. Howard., 2000], which has been subjected to processes of supergene deterioration. The deterioration profile type includes, from top to bottom, the following horizons, which have specific hydrodynamic properties.

The otherness covers the "healthy" rock on a variable thickness (from 0, where the horizon is eroded to several tens of meters). This compartment is characterized by a significant porosity of interstice (within granite porphyritic, the effective porosity can exceed $5 \%$ ) and by a relatively low permeability. When it is saturated with water, this compartment provides a function of capacitive storage of groundwater in the aquifer [JC Maréchal et al., 2003].

The fissured horizon consists of hard rock, affected, on several tens meters of thickness, by the presence of fissure, decreasing frequency with the depth. These cracks, whose origin was associated a long time with "superficial decompression", resulting also from the deterioration processes [R. Wyns et al., 1999]. Their genesis is mainly due to alteration of phyllitic minerals (especially biotite), which swelling causes this fissure [JC Maréchal et al., 2003]. Within textured isotropic rocks (granites, for example), the fissure is expressed preferentially along sub horizontal plans, perpendicular to minimal constraint. Therefore, these plans are generally parallel to the morphology of contemporary deterioration. Within not folded anisotropic rocks (foliated granites, gneiss), the cracking remains planar, but its direction and intensity are determined by the angle between the foliation and topographic surface. Within intensely folded rocks (Schist, mica schist), cracking has a generally random orientation, even at the scale of the outcrop. At the top of the fissured horizon, the frequency of micro cracks becomes close to the grain size of the rock (about one millimeter), marking the transition with otherness's overlying [JC Maréchal et al., 2003]. An important consequence of these methods of genesis is that the fissured horizon of granite is parallel to the paleo-surfaces of deterioration. This horizon ensures transmissive function of the aquifer and is collected by most drillings carried out in the base area.

The importance of couple fracturing- alteration is undeniable in the crystalline rocks because groundwater is limited to the secondary structures where voids were produced by combined action of tectonics and alteration. 
The massive parts of rock can contain water only if the secondary openings side are present, because matrix porosity and primary permeability induced of the most crystalline rocks are extremely low [Issiaka S., John B., 1999].

\section{Physical context of study}

Located between $11^{\circ}$ and $16^{\circ}$ of northern latitude and $20^{\circ}$ at $23^{\circ}$ longitude East, Ouaddaï geographic is limited to north by the massive of Ennedi, in the west by the depression of Mochta, east by the Republic of Sudan and in the South by the Central African Republic. Ouaddai geographic is located almost entirely in the Sahelian zone and extends of about $150000 \mathrm{~km}^{2}$ along Chad's eastern border, thus including the two prefectures of Biltine and Ouaddai. It is characterized by three climatic zones from south to north [G. Joseph, 1980]: the Sahelian-Sudanian zone, the Sahelian zone and the Sahel-Saharan zone. (i) The Sahelian-Sudanian zone is bounded by isohyets 750 and $600 \mathrm{~mm}$. The duration of the rainy season is about five months per year and is distributed from May to September with a peak in July-August [H. Plote, 1970]. The vegetation is characterized by sparse savannah not very dense and gradually sparse northward. (ii) The Sahelian zone is bounded by isohyets 600 and $300 \mathrm{~mm} /$ year. It has an average duration of rainy season of five months (May to September) with maximum rainfall in August. Evaporation is estimated at $4500 \mathrm{~mm} /$ year (about $10 \mathrm{~mm} /$ day). The trees are rare and they are replaced by shrubs among which there are thorny. Under these shrubs installed an herbaceous carpet of pseudo-steppe type. (iii) At the Sahelo-Saharan zone, the rainfall is less than $200 \mathrm{~mm} /$ year. The differences between the minimum and maximum temperatures are high (in the order of $40^{\circ} \mathrm{C}$ ). It is the most arid of Ouaddaï. The months most rainy are July and August. The vegetation is characterized by rare grasses. However, inside the same zone, the vegetation varies with soil type on which it is installed.

The hydrographic network is constituted of the ouadis (local terminology to designate the intermittent rivers of Ouaddaï) flowing towards tornado. About them, Texier (1960) writes: "we are far from Classic River whose flow rate grows by successive tributaries". The ouadis occur at the crest lines and flowing generally towards the west on the Chadian basin (itself divided into NW and SW side) and towards the east on the Sudanese side along the slopes. On the Chadian basin, they are thrown either in a lake (Batha is thrown into Lake Fitri), or they disappear beneath the dunes forming downstream of them the vast marshes: the "Nagas". The flow direction is generally E-W or NE-SW, rarely N-S except for Batha tributaries.

Geologically, the region belongs to large batholitic of granite calco-alkaline of Precambrian, called "regional granite" Plotte, 1970], crossed by many intrusions: granitites acids (alkaline granite) have basic (grano diorites), pegmatite and quartz. The basement is everywhere outcrops or sub-outcrops beneath a thin cover of Quaternary sandy silt deposit from the surrounding reliefs. By places a layer of otherness's granular develops, thin given the low efficiency of the current climate. Two tectonic phases have affected the Ouaddaï [J. Sonet., 1963]. One, of folding and previous to the Paleozoic sandstone has affected the basement and allowed the installation of wrinkles. The other, brittle, is at the origin of the installation of veins and faults. It was held at the Paleozoic and Tertiary. Probably during this phase that the Ouaddaï has been shaped in tiers, one of which is the piedmont.

From the hydrogeological view point, we come cross in Ouaddaï geographic the classic superposition of the superficial porous tank (alluvium and otherness's) and a discontinuous aquifer hosted by fractures of the basement [Cefigre, 1990]. These aquifers are located in zone of basement outcrops and where this one is sub-outcrops, including under several meters of covering thickness (otherness's and Quaternary deposits and Tertiary), configuration which we found on the whole Ouaddaï geographical [Mr. Steenhoutdt., 1993]. The geometry of aquifers tanks include: (i) covering formation likely, under certain conditions, to contain a resource of sub-surface circumscribed within space limits of the shop rock. (ii) The bedrock formations, under their various lithology and the stages of evolution and deterioration, with capacitive function provided by otherness's clayey and sandy-clay saturated and, possibly by granular arena preceding transition zone with boulders and cracking's dense marking the forehead of deterioration and breakdown of bedrock; a transmissibility function provided by surface of discontinuities of bedrock (fissures, fractures, lithological contacts) to selective spatial distribution, possibly homogenized by the presence of transition zone and / or granular saturated arenas developed [M. Steenhoutdt., 1993]. The low and irregularity precipitation coupled with the importance of evaporation and transpiration, allows only low infiltration estimated at $40 \mathrm{~mm}$ per year [Moussie., 1986]. These conditions do not make it possible to maintain saturation the superficial aquifer [Engalenc et al., 1981] and the static level is established within the fractured bedrock. This discontinuous aquifer is a reflection of the fractal distribution of fractures in reservoir rock. In Chad, where the clay orientation is poorly developed, the location of fracture aquifers is not at all sensitive to conventional geophysical prospecting, including geo-electric [Gombert, 1997 \& Ouedraogo, 1988]. 


\section{Methodology}

The cartographic database used in this study include: the structural map of the Ouaddaï, as modified by Gachet A in 2004 and 2005, and Ragot J, M.2005 [Marc-André Bünzli. Yves Haeberlin., 2005]. The suture line separates a metamorphic filed in the south from a basement with granitic prevalence in north. Map background with topographic relief SRTM shaded in $45^{\circ}$ (NASA.SRTM); the watersheds map of Chad eastern whose the quotient $\mathrm{km}$ per $\mathrm{km}^{2}$ of river makes it possible to evaluate the type of flow regime and the potential of basement recharge; the hydrogeological and geological maps extracted respectively from the explanatory leaflet of the hydrogeological map of the east [Marc-André Bünzli. Yves Haeberlin., 2005] and of the hydrogeological synthesis of data relatingto the western and southern piedmont of the massif of Ouaddaï [Djoret Daira., 1992]; the stereotypes resulting from the interpretation of satellite images LANDSAT 7 ETM + in panchromatic mode realized by UNHCR in 2005 were also of paramount importance in this study. In addition to these maps and images, the Directorate of the Hydraulics Field Knowledge (DHFD) of the Ministry of Water has placed at our disposal a database of hydraulic structures made by the various projects that have succeeded in this area and those carried out by NGOs. Thus, we identified 1758 hydraulic structures of any kind (boreholes, wells) and whose 717 were retained our attention for having details information's. This information's are summarized as hydrogeological parameters, the nature of the crossing structures and the types of hydraulic structures made, such as wells, boreholes and piezometers.

MapInfo7.8 software was a key tool determining for the cartography of the maps. Thus, from the structural map we had taken over the lineaments and structural anomalies under MapInfo7.8 after having to proceed to the calibration of the latter with 25 points for a maximum error of pixels equal to 5 (Figure 1). Then, the geographical coordinates of the 717 hydraulics work in Degree Minute Second (DMS) identified in X, Y and converted into Decimal Degree (DD). Those were plotted (Figure 2) on the maps carried out of the UNHCR/RTF [Marc-André Bünzli. Yves Haeberlin., 2005], in order to allot to each work its geological parameters, its watershed and its attributes, its location compared to a dyke, a fault. The juxtaposition of different tables, that is to say, the works table on the lineaments table gives us a simplified structure map of establishment of positive and negative works. This map allows us to highlight the productivity of these works according to their location. That is to say, the rate of positive and negative works obtained despite the resources mobilized and the methods of exploration and exploitation of water used in the Ouaddai geographic area. The satellite images LANDSAT 7 ETM +, multispectral in panchromatic mode, whose interpretation was made by the UNHCR show innumerable structural formations with some precision. Thus, we carried out the systematic cartography of the dykes and faults through MapInfo7.8software. The inventory of their orientation from their route on the map made it possible to highlight the main directions of the extension and compression movements which have affected the study area. The cartography of these various structures (dikes and faults) also allowed us to understand the hydrogeological context in order to locate sites suitable for the establishment of hydraulic works in the basement of Ouaddaï geographic.

\section{Results and discussion}

The extraction of lineaments has led to the establishment of the map of the structural frame of the study area. On the one hand, the juxtaposition of the hydraulic works and the main structural allowed us to obtain structural map and establishment of hydraulic works; and on the other hand, the compilation of different catchment area with principal structural formations gave catchment area map and structural formations of Ouaddaï Geographic.

The parameter study on the productivity of drilling is maximum exploitation flow rate, parameter generally available on the projects of Hydraulic villager and most representative of power draining fractures among known parameters for these drillings. It is available for all drilling inventoried in the area. This flow rate is given to be calculated on the basis of pumping test results by applying standard method defined by CIEH (1988). The flow rate of drilling that has not been tested, that is to say the least productive wells, is recorded like null.

In our study area, structural analysis allowed identification of several lineaments, usually corresponding to fractures, faults, veins or dikes. These rosettes of directions resulting from statistics carried out from cartography of HCR give regional directions, associated with opening of Atlantic rift and the Red Sea more recently. We note the directions $\mathrm{N} 70^{\circ} \mathrm{E}$ to $\mathrm{N} 50^{\circ} \mathrm{E}$ and $\mathrm{N} 110^{\circ} \mathrm{E}$ to $160^{\circ} \mathrm{E}$ in the northern part and $\mathrm{N} 50^{\circ} \mathrm{E}$ to $70^{\circ} \mathrm{E}$ and $\mathrm{N} 110^{\circ} \mathrm{E}$ to $120^{\circ} \mathrm{E}$ in the southern part [Marc-André Bünzli. Yves Haeberlin. 2005]. However, for the dykes, one note the directions $\mathrm{N} 5^{\circ} \mathrm{E}$ and $120^{\circ} \mathrm{E}$ for the quartz veins, especially present in the southern zone, $\mathrm{N} 60^{\circ} \mathrm{E}$ for the basic dykes and $\mathrm{N} 60^{\circ} \mathrm{E}$ to $70^{\circ} \mathrm{E}$ acids dykes. In comparison, the rosettes established from lineaments of aerial photographs, for positive and negative drilling are provide in the Figure 3. The rosettes show the regional direction namely $\mathrm{N} 60$ and $110-130^{\circ} \mathrm{E}$. At these regional directions, added the $\mathrm{N} 40^{\circ} \mathrm{E}$ direction, which is not 
highlight by UNHCR study, but which is present on all types of drilling. The distribution of drillings shows that the directions $\mathrm{N} 60^{\circ} \mathrm{E}$ and $90^{\circ} \mathrm{E}$ give more positive drilling, whereas those $\mathrm{N} 20,80,110$ and $130^{\circ} \mathrm{E}$ are often the most negative.

In considering direction of extension $\mathrm{N} 60^{\circ} \mathrm{E}$ for the opening of the Red Sea (the most recent direction), then the parallel fracturing theoretically have tendency to open or reopen whereas the perpendicular directions are closed. In this case, the associated shear fractures are around $45^{\circ}\left(\mathrm{N} 10^{\circ} \mathrm{E}\right.$ and $100^{\circ} \mathrm{E}$ approximately). In complement, the influences of the Atlantic rift are situate towards $\mathrm{N} 130^{\circ} \mathrm{E}$ in opening, closing at $\mathrm{N} 40$ and $\mathrm{N} 85^{\circ} \mathrm{E}$ and shearing at $175^{\circ} \mathrm{E}$. These considerations have values only if the influence of the Mediterranean plates does not create compressive constraint in the area and if there is no major accident redistributing locally the constraint field. There is general indication which will be able to guide partially hydrogeologists during aerial photographs study. These regional considerations are in phase with previously established rosettes.

It should be noted also that the result of the analysis of our data shows that most productive hydraulic works are located in basin with density hydrographic coefficients higher and middle basins and especially in groundwater flow direction. The distribution of the hydraulic works according to the organizations, quantity and ratio productivity are determined as follows (Table 1).

It appears that about $60 \%$ of hydraulic works are dry and nearly $20 \%$ have a flow rate raging between $0.5-1.5$ $\mathrm{m}^{3} / \mathrm{s}$. These results raise pertinent questions about methods of exploration and establishment of drilling in the basement areas. For this propose, many dry boreholes are mostly localized on anomalies associated with fault zones very wide and very marked and conductive. These zones often correspond to shearing zones. On this kind of anomaly, the drillings should be established on geophysical gradients, but not in the center of anomaly which could be systematically plugged. Thus, the areas moderately resistant above the fault which are superimposed on the anomalies of deeper fractures can correspond to the less fractured levels and limiting the buffer reservoirs. It may also include the cemented areas which the electrical tomography in pole dipole directs and inverse can refine the establishment.

The approach combining inventory of the lineaments on satellite image, exogenous data and field work led establishment of fractures and understanding geological structures [Berard et al, 1990]. Thus, the detailed map of lineaments (Figure 4) was achieved through an interpretation of images derived from different processing techniques. This map shows an important density of lineaments of varying sizes, up to several hundred meters. This study of lineaments highlighted the various nodes of fractures which, constituted by the intersections of fractures have a significant water potential. They can help to direct the recognition campaigns by defining the areas potentially favorable and to select the specific sites for drilling establishment.

Several studies conducted in different contexts have shown interest and importance to the analysis of lineaments on satellite images for hydrogeological exploration. Dutartre et al. (1990), in a study carried out in Burkina Faso, have been set from SPOT imagery the repetitive interpretation rulers in three complementary fields: research of fracture zones, the seepage areas delimitation and areas identification having an agronomic potential. Berard et al. (1990), in a study for the water supply of an industrial complex (gold mine) in Sudan, have shown the contribution of Landsat images combined with previous studies to establish drilling and highlight the existence of new aquifers. In a study of lineaments in the region of Marahoué (Ivory Coast) on Landsat images, Biémi et al. (1991) have established a diagram making it possible to define drillings in fissured basement in order to control future drilling establishment and to ensure their management.

From the general point, the studies by satellite photos are very important for general knowledge of the perimeter study. On the order hand, it is clear that the scale of cartography only helps very rarely for specific establishment on the field. The correlations to the faults, dykes, watex zones, geology, watershed etc ... are interesting, even fundamental if there has a margin of establishment of several kilometers.

In all this analysis, we have made from the hydrogeological divisions carried out, given the general recommendations in order to allow raising some ambiguities. They are: (i) carry out drilling in the border of the large and conductive geophysical anomalies. Indeed, it is possible that these anomalies correspond to an important shearing. Thus, hydraulic gradient upstream can be aquifer in this case. (ii) Carry out drilling just in the inselbergs border to verify certain hydrogeological assumptions which consist in saying that border of these massive outcrops is aquifer. (iii) Carry out drilling in hydraulic border upstream of dyke, acid, basic and quartz vein, to check any aspect of the hydraulic barrier and / or drain of these structures. All these considerations are essential to increase significantly the success rate of the drillings in the basement areas. 


\section{Conclusion}

Using the approach combining interpretation of satellite imagery, the exogenous data and the field work, has allowed the cartography and the analysis of fractures and the profile deterioration associated with them. This makes it possible to guide the drilling establishment able to provide a large flow rate. Castaing et al. (1989) have shown the necessity of using aerial photography or the satellite imagery to cartography the traces of these fractures on the ground. Indeed, the hydraulic works carried out in of these fractures mapped, or better still to the place where two or more fractures intersect provide generally a great groundwater flow rate. However, the principal criteria were the presence of at least two lineaments of kilometric extension crossing a node of fault; the proximity of ouadi to support the recharge; certain tectonic directions potentially more favorable as knowing $\mathrm{N} 40$ to $60^{\circ} \mathrm{E}$ and $\mathrm{N} 110$ to $130^{\circ} \mathrm{E}$; the possible presence of dyke to form watertight barriers or the drains; the possible presence of coarse-grained lithology etc..... These brittle accidents have hydrogeological role. Indeed, to ensure an optimum flow rate for the drilling, the research for fractures or fracture intersections is advised. Thus for this study we have identified several fractures that present the interest sure for the future campaigns of rural water supply.

\section{Acknowledgement}

This research was supported by China Scholarship Council and China University of Geosciences (Wuhan), School of Environmental Studies. We wish to thank the China Scholarship Council, the Hydrogeology and Water Resources Department of Environment Studies School, China University of Geosciences in Wuhan and Water Ministry of Chad Republic for their support.

\section{References}

CEFIGRE. (1990). Summary of knowledge on the hydrogeology of West Africa. Crystalline and metamorphic basement. Old Sedimentary, collection Maitrise de l'Eau, 47p., Ministry of Cooperation and Development, Paris.

Berard, P., Castaing, C. \& Scanvic, J. Y. (1990). Water supply of the Gold mine in Hassi (Sudan): Impact of remote sensing study. Hydrogeology 2, 101-111

Biémi, J., Deslandes, S., Gwyn, Q. H. J. \& Jourda, P. (1991). Geology and networks of regional lineaments of the catchment area of upper Marahoué (Ivory Coast): cartography using Landsat TM data and total magnetic field. In: Remote Sensing and Management Resource, Vol. VII, 135-145. Association Québécoise de Télédétection.

Djoret Daira. (1992). Synthesis of the hydrogeological data on the western and southern piedmont of the Massif of Ouaddai. PhD Thesis.

Dutartre, P., King, C, Motti, E. \& Pointet, T. (1990). Use of SPOT imagery in hydrogeological prospection in Burkina Faso. Hydrogeology 2, 146-154.

Engalenc M., Grillot J.C., Lachaud J.C. (1981). Method of study and research of groundwater in crystalline rocks of West Africa. Geo-hydro-LCHF, House-Alfort, France

Gombert P. (1997). Variabilité spatiale de la productivité aquifère du socle sahélien en hydraulique rurale. In: Hard Rock Hydro-systems, POINTET T. ed IAHS Publ. no 241, 113-122

Issiaka S., Jean B. (1999). Remote sensing and GIS for the study of crystalline basement aquifers of Odienné (North-West of Cote d'Ivoire). OPA (Overseas Publisher Association), vol.1, p.47-64

J-C Maréchal et al. (2003). Vertical anisotropy of the permeability of the fissured horizon of the basement aquifers: correlation with the geological structure of the deterioration profile.

Joseph G. (1980). The hydrogeology of Ouaddaï (eastern Chad) in the geological context and hydro-climate of the Republic of Chad. University of Nice, $182 \mathrm{p}$.

Lamine. Y. Kosso. (1997). Report on the ending of short drilling on the crystalline basement areas north and center of the project, November 97 page 5.

Marc-André Bunzli., Yves Haeberlin. (2005). Hydrogeological Map of Eastern Chad: Explanatory Notes.

M. Steenhoutdt. (1993). Program of hydraulic villager and Pastoral in the Salamat, Ouaddaï and Biltine. Technical and financial feasibility Study. BRGM

Moussie B. (1986). Map of potential groundwater resources of the West and Central Africa at 1/5000 000 . BRGM, Orléans, France, Report 86 AFO 178 EAU, 82 p. 
Ouedraogo B. (1988). Drilling Productivity on crystalline and metamorphic basement in sub-Sahelian region. Th Doct., Univ. Le Mans, France 252 P

Patrick L., Robert W. (2005). Basement aquifer: New concepts. Application to the prospecting and water resources management. Geosciences No. 2.

Plote H. (1970). Quadrennial program of hydraulic development of Ouaddaï: hydrology of Ouaddai. Synthesis Report. Vol.1 and 2. BRGM Paris., $448 \mathrm{p}$

R. Taylor., K. Howard. (2000). A tectono-geomorphic model of the hydrogeology of deeply weathered crystalline rock: evidence from Uganda, Hydrogeol. J. 8 (3) 279-294.

R. Wyns., JC. Gourry., J.-M. Baltassat., F. Lebert. (1999). Multi-parameter characterization of the horizons of sub-surface $(0-100 \mathrm{~m})$ in the context of altered bedrock, in: 2nd Symposium GEOFCAN, BRGM, IRD, UPMC, pp. 105-110.

Sonet. J. (1963). Geological map at 1/500 000 and explanatory, Niéré Sheet.

Texier. J. (1960). Hydrological research in the areas of Batha, Guéra and Ouaddai (data bases for the development of water points on the surface or at a shallow depth). ORSTOM., CRT, hydrology section. $71 \mathrm{p}$.

Table 1. Distribution of works according to the organizations depending on their productivity

\begin{tabular}{|c|c|c|c|c|c|c|c|}
\hline \multirow[b]{3}{*}{ Organizations } & \multirow{3}{*}{$\begin{array}{l}\text { Number of } \\
\text { works carried } \\
\text { out }\end{array}$} & \multicolumn{6}{|c|}{ ratio Productivity of the work carried out } \\
\hline & & \multicolumn{5}{|c|}{ Positive } & \multirow[t]{2}{*}{ Negative } \\
\hline & & $\begin{array}{l}0.5-1.5 \\
\mathrm{~m}^{3} / \mathrm{s}\end{array}$ & $\begin{array}{l}1.5-5 \\
\mathrm{~m}^{3} / \mathrm{s}\end{array}$ & $\begin{array}{l}5-10.1 \\
\mathrm{~m}^{3} / \mathrm{s}\end{array}$ & $\begin{array}{l}10.1-20 \\
\mathrm{~m}^{3} / \mathrm{s}\end{array}$ & $\begin{array}{l}>20 \\
\mathrm{~m}^{3} / \mathrm{s}\end{array}$ & \\
\hline $\begin{array}{l}\text { PHVOB, GTZ, } \\
\text { SECADEV, } \\
\text { Almy } \\
\text { Bahaïm.... }\end{array}$ & 660 & $18.94 \%$ & $\begin{array}{l}13.18 \\
\%\end{array}$ & $\begin{array}{l}04.40 \\
\%\end{array}$ & $01.97 \%$ & $01.66 \%$ & $59.85 \%$ \\
\hline TOTALS & $100 \%$ & \multicolumn{5}{|c|}{$40.15 \%$} & $59.85 \%$ \\
\hline
\end{tabular}

PHVOB, Hydraulic Villager Project in Ouaddai and Biltine; SECADEV : Catholic Relief Development; GTZ: Deutsche Gesellschaft Für Technische Zusammenarbeit GmbH (German Society for Technical cooperation); Almy Bahaïm : water for livestock 


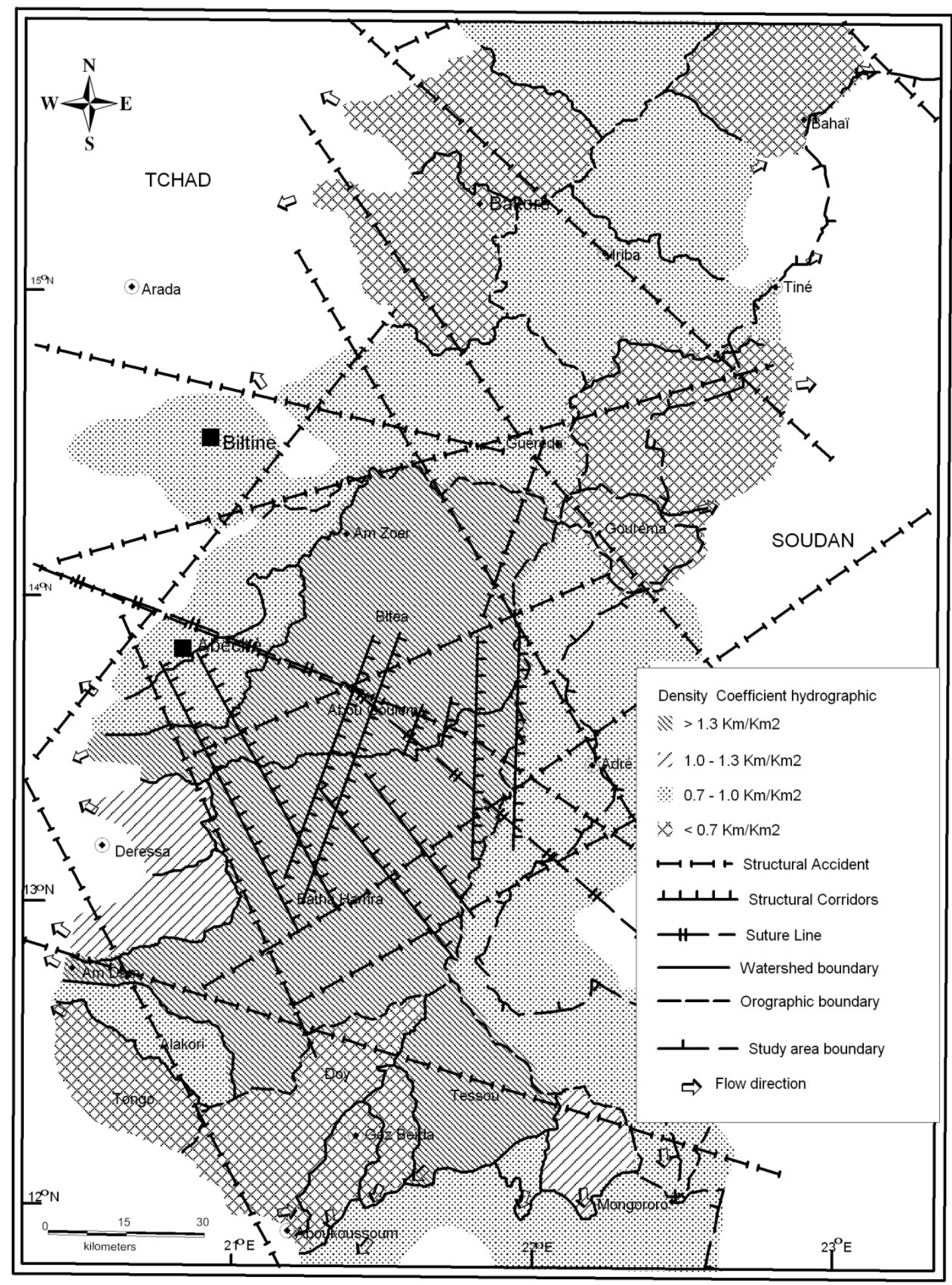

Figure 1. Map of simplified structural formation and watersheds division of Ouaddaï Geographic 


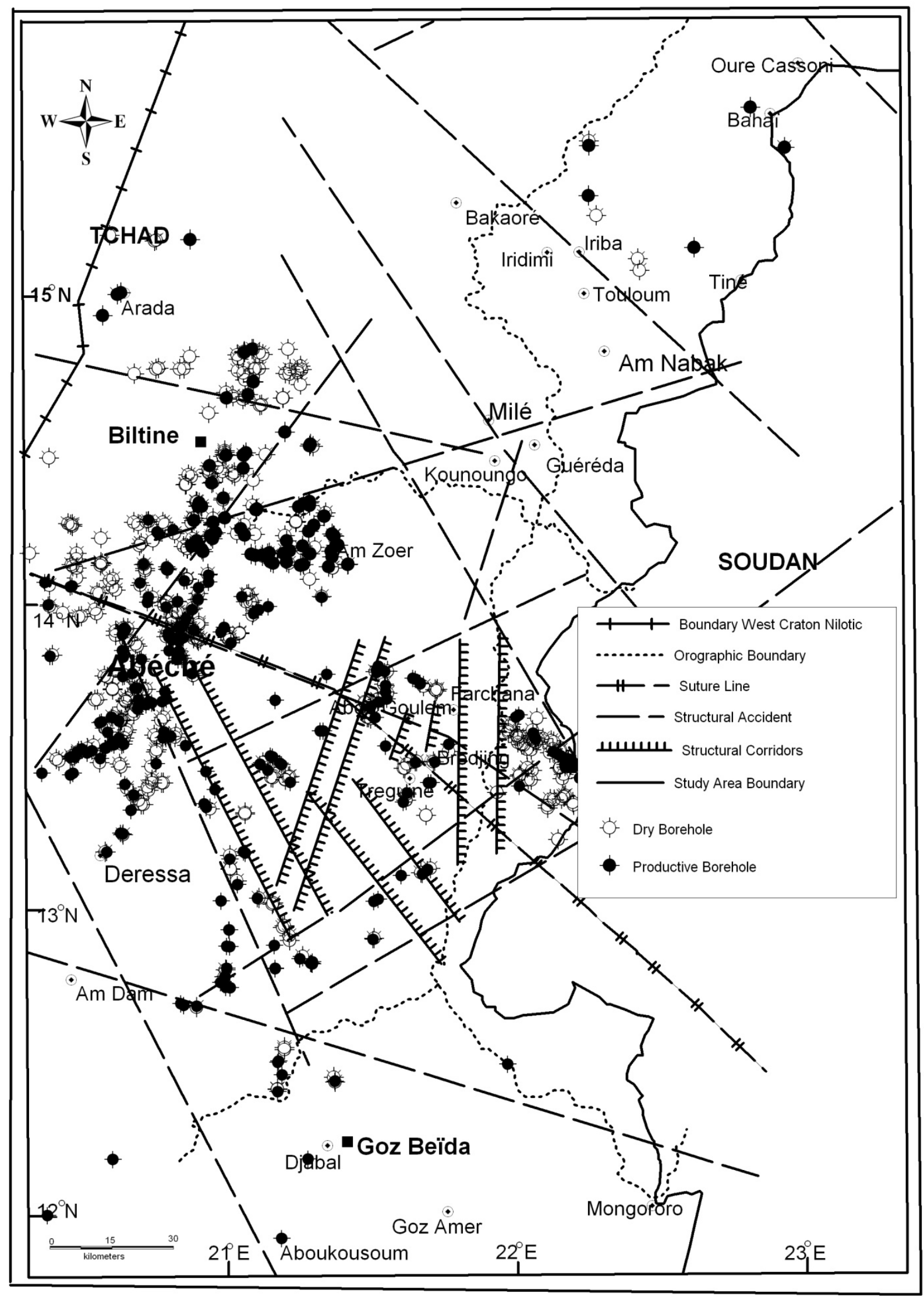

Figure 2. Simplified structural map and of distribution of borehole in Geographical Ouaddaï 


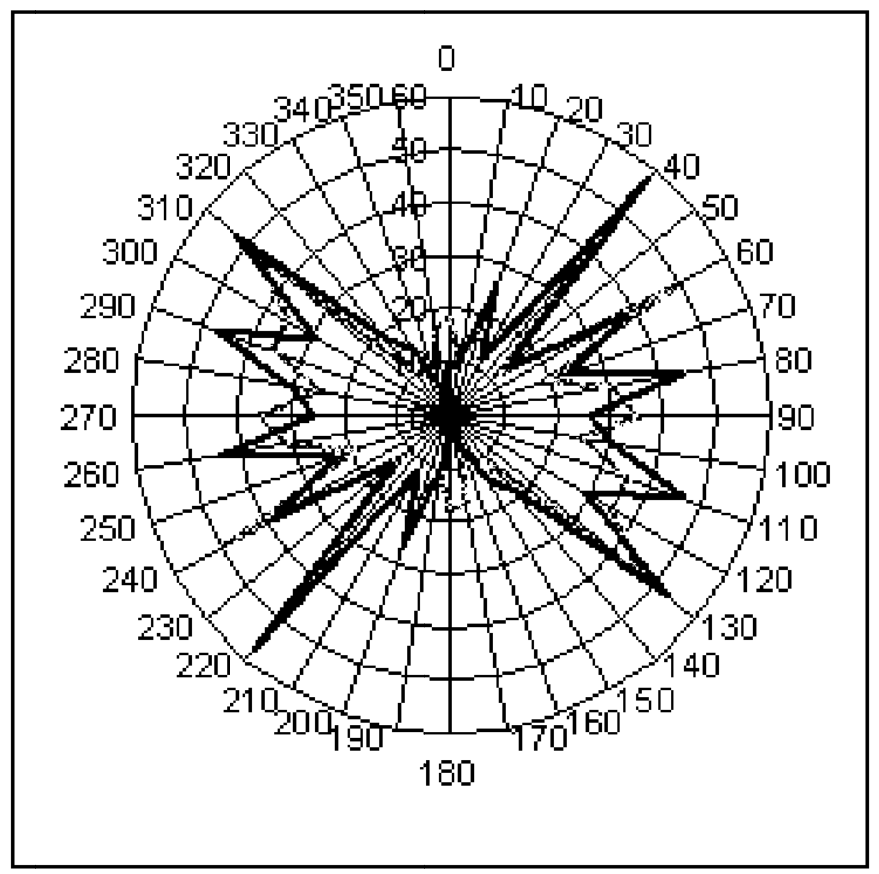

Figure 3. Rosette of the fracturing drilling directions of PHVOB (modified by Ragot JM 2005); Comparison positive drilling / negative drilling 


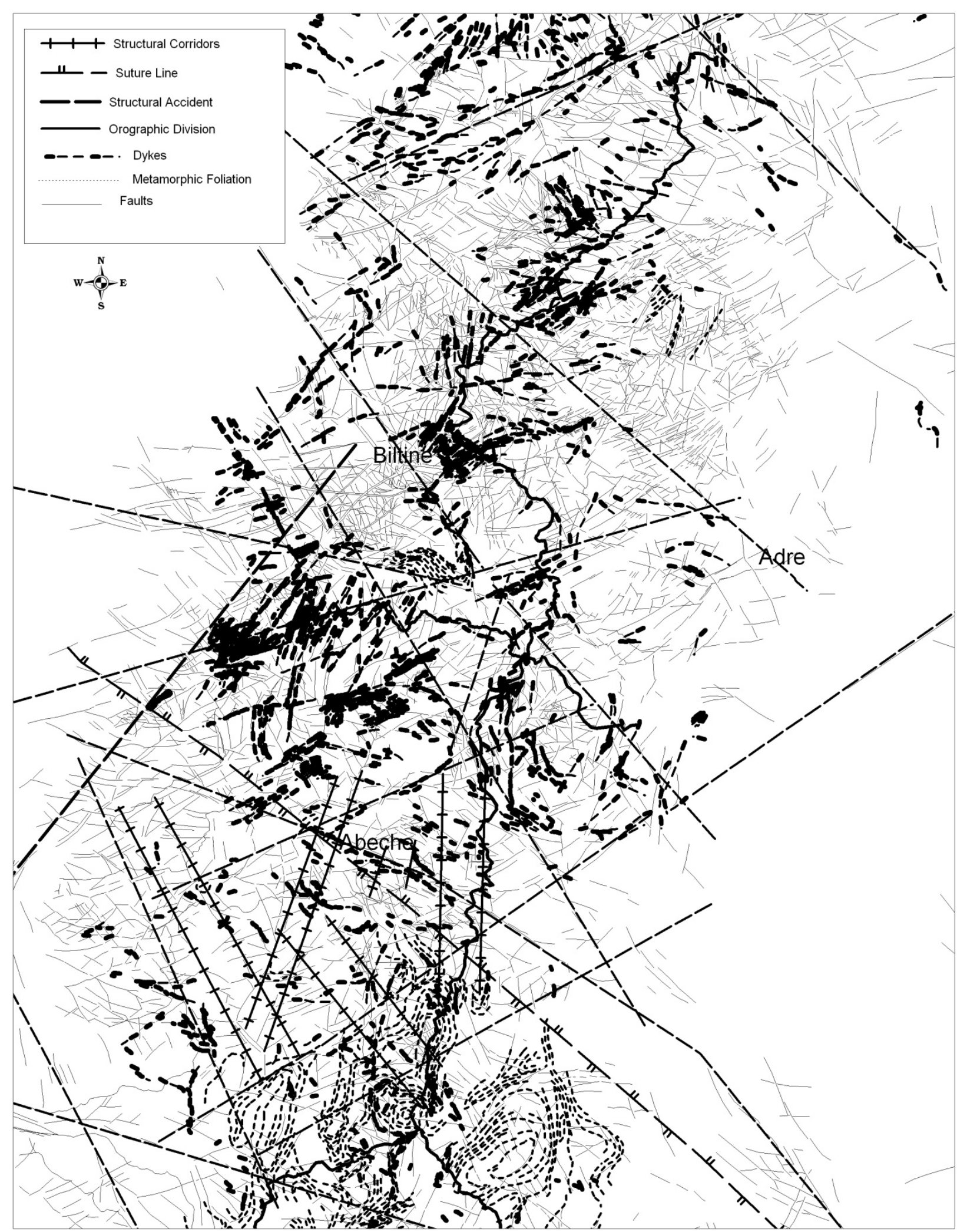

Figure 4. Detailed structural map 